\title{
PRAKTIK ADAT TENTANG KETIDAKBOLEHAN MENIKAH PADA BULAN RAMADAN DAN SYAWAL (NYOWOK) DI DESA SOKONG KECAMATAN TANJUNG KABUPATEN LOMBOK UTARA PERSPEKTIF HAK ASASI MANUSIA
}

(Traditional Practice Concerning Inequality of Marriage in Ramadan and Syawal Months (Nyowok) in The Sokong District of Tanjung District North Lombok District, Perspective of Human Right)

\author{
Sirtatul Laili \\ Fakultas Hukum \\ Universitas Indonesia, Salemba-Jakarta \\ Sirtatul.laili89@gmail.com
}

\begin{abstract}
The marriages done by men and women should have marital conditions. These conditions have been regulated in Law No. 1 of 1974 on Marriage. Likewise, Article 10 of the Law Number 39 Year 1999 on Human Rights regulates the right to have a family and carry on descendants. Of all these rules, there is no prohibition to organize marriage in certain months. However, the people of Sokong village, even though Muslim, still uphold their traditions, which marriages should not take place in certain months. The purpose of this study is to highlight how traditional Nyowok practices in Sokong Village, Tanjung Subdistrict, North Lombok Regency, and a review of Human Rights. The research method used is qualitative, which used to examine conditions that occur in the field related to the problems of this study. It is a descriptive research with primary and secondary data sources. The results show that Nyowok adat is a practice related to the prohibition of marriage in the month of Ramadan and Shawwal. The inability to get married in the month of Ramadan and Syawal due to certain reasons should see the impact that is happening to the community and should pay attention to the right of family and continuing offspring, which are human rights.
\end{abstract}

Keywords: marriage; ramadan, syawal; human rights.

\begin{abstract}
Abstrak
Perkawinan yang dilakukan antara laki-laki dan perempuan harus memilik syarat-syarat perkawinan. Syarat tersebut telah diatur dalam UU Nomor 1 Tahun 1974 dan Undang-Undang Nomor 39 Tahun 1999 Pasal 10 mengatur tentang hak berkeluarga dan melanjutkan keturunan. Dari semua aturan tersebut tidak ada satu pun larangan mengisyaratkan perkawinan pada bulan-bulan tertentu, namun masyarakat Desa Sokong walaupun beragama Islam, masih memegang teguh adat. Di mana perkawinan tidak boleh dilangsungkan pada bulanbulan tertentu. Adapun tujuan dari penelitian ini untuk menyoroti bagaimana Praktik adat nyowok di Desa Sokong Kecamatan Tanjung Kabupaten Lombok Utara beserta tinjauan Hak Asasi Manusia. Metode penelitian yang digunakan adalah kualitatif, yaitu metode penelitian yang digunakan untuk meneliti kondisi yang terjadi di lapangan yang terkait permasalahan dari penelitian ini. Penelitian ini bersifat deskriptif, sumber data primer dan sekunder. Dengan ketidakbolehan menikah pada bulan Ramadan dan Syawal dikarenakan alasan-alasan tertentu hendaknya melihat dampak yang terjadi bagi masyarakat dan hendaknya memperhatikan hak berkeluarga dan melanjutkan keturunan yang merupakan hak asasi manusia.
\end{abstract}

Kata kunci: perkawinan; Ramadan; Syawal; hak asasi manusia.

\section{PENDAHULUAN}

Hak asasi manusia pada dasarnya merupakan hak yang paling hakiki yang dimiliki oleh setiap manusia dalam kapasitasnya sebagai individu. Sepanjang hak ini tidak mengganggu hak orang lain, hak ini tidak boleh di ganggu gugat oleh siapa pun, bahkan penjaminnya harus dilindungi oleh negara 
sekalipun. Hak ini muncul dengan tujuan untuk melindungi manusia sebagai individu seutuhnya ${ }^{1}$.

Disisi lain, secara filsafati juga merupakan pemberian Tuhan kepada setiap makhluknya yang tidak dapat ditinggalkan dengan alasan adapun. Hak asasi manusia ini antara lain hak untuk hidup, hak untuk beragama, hak untuk membina rumah tangga satu sama lain, dll.

Berlandaskan pada ketetapan MPR Nomor XVII/MPR/1998, pada tanggal 23 September 1999 diberlakukanlah Undang-Undang Nomor 39 Tahun 1999 tentang Hak Asasi Manusia yang lazimnya disebut UU HAM. ${ }^{2}$ Dalam UU ini, selain diatur mengenai "hak asasi manusia dan kebebasan dasar manusia ditegaskan pula beberapa hal yang berkaitan dengan kewajiban dasar manusia” ${ }^{3}$. Hakhak asasi manusia dan kebebasan dasar manusia yang ditetapkan dalam UU HAM ini antara lain meliputi:

1. Hak untuk hidup ${ }^{4}$

2. Hak berkeluarga dan melanjutkan keturunan ${ }^{5}$

3. Hak mengembangkan diri ${ }^{6}$

4. Hak memperoleh keadilan ${ }^{7}$

5. Hak atas kebebasan pribadi ${ }^{8}$

6. Hak atas rasa aman ${ }^{9}$

7. Hak atas kesejahteraan ${ }^{10}$

8. Hak turut serta dalam pemerintahan ${ }^{11}$

9. Hak Wanita ${ }^{12}$

10. dan Hak anak. ${ }^{13}$

Kenyataan keseharian manusia dapat dilihat bahwa orang yang berlainan kelamin antara lakilaki dan perempuan dapat menjalankan kehidupan berumah tangga dalam suatu ikatan perkawinan.

1 Leni Marlina Nurhidayatuloh, "Perkawinan Di Bawah Umur Perspektif HAM,” Al-Mawarid XI (2011): 211.

2 Satya Arinanto, Hak Asasi Manusia Dalam Transisi Politik Di Indonesia (Jakarta: Pusat Studi Hukum Tata Negara, 2018), 16.

3 “Undang-Undang Republik Indonesia1999, UndangUndang Republik Indonesi Nomor 39 Tahun 1999 Tentang Hak Asasi Manusia,” 1999.

4 Ibid., Pasal 9, Ayat (1), (2), Dan (3)

5 Ibid., Pasal 10 Ayat (1), Dan (2)

6 Ibid., Pasal 11, Pasal 12, Pasal 13, Pasal 14, Pasal 15, Dan Pasal 16

7 Ibid., Pasal 17, Pasal 18 Ayat (1), Ayat (2), (3), (4), Dan Pasal 19.

8 Ibid., Pasal 20, Ayat (1), Dan (2), Pasal 21, Pasal 22 Ayat (1) Dan (2), Pasal 23 Ayat (1) Dan (2), Pasal 24 Ayat (1) Dan (2), Pasal 25, Pasal 26 Ayat (1) Dan (2),Dan Pasal 27 Ayat (1) Dan (2).

9 Ibid., Pasal 28 Ayat (1) Dan (2), Pasal 29 Ayat (1) Dan (2), Pasal 30, Pasal 31 Ayat (1) Dan (2), Pasal 32, Pasal 33 Ayat (1) Dan (2), Pasal 34 Dan Pasal 35

10 Ibid., Pasal 36 Ayat (1), (2), Dan (3), Pasal 37 Ayat
Dimulainya kehidupan perkawinan mulanya mulai dengan landasan atau kaidah-kaidah hukum yang berlaku, baik hukum agama, hukum adat maupun hukum nasional. ${ }^{14}$

Perkawinan sebagai langkah awal dalam membentuk suatu keluarga kecil yang bahagia dan sejahtera lahir batin sesuai yang telah diamanatkan oleh Undang-Undang Dasar 1945 di mana Negara menjamin kepada tiap-tiap Warga Negara Indonesia untuk membentuk keluarga, sebagaimana Pasal 28 B Ayat (1) Undang-Undang Dasar $1945^{15}$ yang berbunyi "setiap orang berhak membentuk keluarga dan melanjutkan keturunan melalui perkawinan yang sah”.

Sama halnya dengan peraturan perundangundangan No. 1 Tahun $1974 .{ }^{16}$ Pasal 6 Yang menyebutkan sahnya perkawinan harus memenuhi syarat di antaranya: a). Perkawinan didasarkan atas persetujuan kedua calon mempelai. b). Untuk melangsungkan perkawinan seorang yang belum mencapai umur 21 (dua puluh satu) tahun harus mendapat izin kedua orang tua. c). Dalam hal seorang dari kedua orang tua meninggal dunia atau dalam keadaan tidak mampu menyatakan kehendaknya, maka izin yang dimaksud Ayat (2) Pasal ini cukup diperoleh dari orang tua yang masih hidup atau dari orang tua yang mampu menyatakan kehendaknya. d). dalam hal kedua orang tua telah meninggal dunia atau dalam keadaan tidak mampu untuk menyatakan kehendaknya, maka izin diperoleh dari wali orang yang memelihara atau keluarga yang mempunyai hubungan darah dalam garis keturunan lurus ke atas selama mereka masih

(1), Dan (2), Pasal 38 Ayat (1), (2), (3) Dan (4), Pasal 39, Pasal 40, Pasal 41 Ayat (1) Dan (2), Dan Pasal 42

11 Ibid., Pasal 43 Ayat (1), (2) Dan (3), Dan Pasal 44

12 Ibid., 45, Pasal 46, Pasal 47, Pasal 48, Pasal 49 Ayat (1), (2), Dan (3), Pasal 50, Dan Pasal 51 Ayat (1), (2) Dan (3)

13 Ibid.,Pasal 52 Ayat (1),Dan (2), Pasal 53 Ayat (1), Dan (2), Pasal 54, Pasal 55, Pasal 56 Ayat (1), Dan (2), Pasal 57 Ayat (1), (2) Dan (3), Pasal 58 Ayat (1) Dan (2), Pasal 59 Ayat (1) Dan (2), Pasal 60 Ayat (1) Dan (2), Pasal 61, Pasal 62, Pasal 63, Pasal 64, Pasal 65, Dan Pasal 66 Ayat (1), (2), (3), (4), (5), (6) Dan (7).

14 Atun Wardatun, et., al,Jejak Jender Pada Budaya Mbojo, Samawa Dan Sasak Di Nusa Tenggara Barat (Mataram: Pusat Studi Wanita, 2009), 71-72.

15 Pasal 28 B Ayat (1) Undang-Undang Dasar 1945 Berbunyi "Setiap Orang Berhak Membentuk Keluarga Dan Melanjutkan Keturunan Melalui Perkawinan Yang Sah

16 Menteri Sekretaris Negara, “Undang-Undang Republik Indonesia Nomor 1 Tahun 1974 Tentang Perkawinan,” 1974. 
hidup dan dalam keadaan menyatakan kehendaknya. e). Dalam hal ada perbedaan antara orang-orang yang dimaksud dalam Ayat (2), (3) dan (4) Pasal ini, atau salah seorang atau lebih di antara mereka tidak menyatakan pendapatnya, maka Pengadilan dalam daerah tempat tinggal orang yang akan melangsungkan perkawinan atas permintaan orang tersebut dapat memberikan ijin setelah lebih dahulu mendengar orang-orang yang tersebut dalam Ayat (2), (3) dan (4) dalam Pasal ini ${ }^{17}$.

Selain itu juga UU tersebut tentang larangan perkawinan dalam Pasal $8{ }^{18}$ menyebutkan perkawinan dilarang antara dua orang yang: a). berhubungan darah dalam garis keturunan lurus ke bawah ataupun ke atas; b). berhubungan darah dalam garis keturunan menyamping yaitu: antara saudara, antara seseorang dengan saudara orang tua dan antara seseorang dengan saudara neneknya; c). berhubungan semenda, yaitu mertua, anak tiri menantu ibu/bapak tiri; d). berhubungan susuan, yaitu orang tua susuan, anak susuan, saudara susuan dan bibi/paman susuan; e) berhubungan saudara dengan istri atau sebagai bibi atau kemenakan dari istri, dalam hal seorang suami beristri lebih dari seorang; f). mempunyai hubungan yang oleh agamanya atau peraturan lain yang berlaku, dilarang kawin ${ }^{19}$.

Menurut ketentuan yang ada baik UU No.1 Tahun 1974 dan UU Hak Asasi Manusia di atas, tidak mensyaratkan waktu sebagai syarat sahnya perkawinan, kedua hukum tersebut membolehkan melakukan perkawinan kapan saja selama telah memenuhi rukun dan syarat perkawinan. Namun, dalam praktik di lapangan ternyata masyarakat di pulau Lombok terpecah pelaksanaan kegiatan perkawinan menjadi tiga macam, ada yang melangsungkan perkawinan berdasarkan hukum Islam, ada yang melangsungkan perkawinan berdasarkan hukum positif, tetapi ada juga yang melangsungkan perkawinan berdasarkan hukum adat. Perkawinan yang dilakukan dalam hukum adat itu terjadi di Desa Sokong Kecamatan Tanjung Kabupaten Lombok Utara. Di mana dalam melangsungkan perkawinan menurut hukum adat di Desa Sokong sebuah perkawinan harus melihat dari beberapa faktor selain dari rukun dan syarat itu. Dalam kegiatan di masyarakat Desa Sokong perkawinan tidak boleh dilakukan pada bulan-bulan tertentu, seperti bulan Ramadan dan 6 hari pada bulan Syawal. Apabila perkawinan dilakukan pada dua bulan tersebut maka perkawinan tersebut

\footnotetext{
17 Ibid., Pasal 6, Ayat (1), (2), (3), (4), Dan (5)

18 Ibid., Pasal 8, Ayat (1), (2), (3), (4), (5), Dan (6)

19 "Undangg-Undang Republik Indonesia Nomor 1 Tahun 1974 Tentang Perkawinan.”
}

dianggap tidak sah menurut hukum adat Sokong. perkawinan itu akan dianggap sah apabila masyarakat membayar denda berupa menyembelih seekor kambing dan memberikan sembelihan kepada fakir miskin. Denda itulah yang dinamakan dalam tradisi adat istiadat Desa Sokong disebut dengan adat nyowok.

Berdasarkan latar belakang di atas mengenai permasalahan yang terjadi di lapangan mengenai ketidakbolehan masyarakat melakukan perkawinan pada bulan Ramadan dan Syawal maka permasalahannya. Pertama, bagaimana praktik adat nyowok di Desa Sokong Kecamatan Tanjung Kabupaten Lombok Utara?. Kedua, bagaimana perspektif Hak Asasi Manusia tentang adat nyowok tersebut?

\section{METODE PENELITIAN}

Macam penelitian yang digunakan peneliti yaitu penelitian kualitatif, yaitu metode penelitian yang digunakan untuk meneliti kondisi yang alamiah, di mana peneliti merupakan instrumen kunci $^{20}$. Adapun alasan peneliti menggunakan jenis penelitian kualitatif, karena penelitian kualitatif memiliki dasar deskriptif guna memahami suatu peristiwa dengan lebih mendalam serta dalam penelitian kualitatif menggunakan landasan teori untuk memfokuskan penelitian serta menekankan pada proses dan makna yang terdapat dalam peristiwa tersebut.

Adapun bahan hukum yang digunakan yaitu bahan hukum primer seperti Undang-Undang Nomor 39 Tahun 1999, Undang-Undang Nomor 1 Tahun 1974. Sedangkan bahan hukum sekunder yang digunakan berupa buku Hak Asasi Manusia Dalam Transisi Politik di Indonesia dan jurnal HAM

Sumber data ada dua: primer dan sekunder. Data primer, sumber datanya diperoleh secara langsung dari sumber aslinya atau sumber utama ${ }^{21}$. Dalam penelitian ini, peneliti menggunakan wawancara dalam mengumpulkan data. Data primer sumber datanya berasal dari hasil wawancara peneliti dengan ketua adat, pemangku adat, tokoh agama dan masyarakat yang terkena dengan denda menikah pada bulan Ramadan dan Syawal tersebut. Sedangkan data sekunder, sumber datanya diperoleh peneliti secara tidak langsung melalui media perantara, seperti buku, jurnal, dan artikel yang terkait dengan permasalahan yang penulis

20 Johan Setiawan Albi Anggito, Metode Penelitian Kualitatif (Sukabumi: CV Jejak, 2018), 7.

21 H.M. Burhan Bungin, Metode Penelitian Kuantitatif (Jakarta: Kencana, 2017), 132. 
teliti. Adapun teknik Pengumpulan data dalam penelitian ini dilakukan melalui beberapa cara, di antaranya adalah: wawancara dan dokumentasi.

Wawancara ada dua yaitu wawancara struktur dan wawancara tidak terstruktur. Teknik wawancara yang penulis gunakan adalah wawancara tidak terstruktur. Artinya, peneliti tidak menyusun terlebih dahulu pedoman pertanyaanpertanyaan yang diajukan kepada informan atau responden. Namun, peneliti hanya menyusun poinpoin besar atau umum dari pertanyaan yang diajukan

Bentuk dokumentasi itu berupa resmi maupun tidak resmi, baik itu berbentuk laporan, surat resmi, buku harian dan semacamnya. Dokumen berkaitan dengan bentuk dokumen yang merupakan informasi, dengan kata lain bahwa metode dokumentasi sebagai sumber informasi merupakan cara pengumpulan data yang dilakukan dengan mempelajari tulisan-tulisan yang ada, serta data sarana dan prasarana yang mendukung pencarian data tersebut. Seperti nama masyarakat yang terkena denda

Metode analisis data adalah tahapan dalam proses penelitian dengan tujuan menginvestigasi, mentransformasi, mengungkap pola-pola gejala sosial yang diteliti agar laporan penelitian dapat menunjukkan informasi, simpulan dan atau menyediakan rekomendasi untuk pembuat kebijakan. ${ }^{22}$ Adapun metode analisis data yang digunakan adalah filosofi atau logika dengan metode induksi yaitu berangkat dari fakta-fakta khusus, peristiwa-peristiwa yang konkret, kemudian dari fakta-fakta khusus atau peristiwa yang konkret tersebut ditarik kesimpulan yang bersifat umum. Merujuk pada pengertian di atas, peneliti menggunakan metode ini adalah untuk menyimpulkan hasil wawancara dan dokumentasi.

\section{PEMBAHASAN}

\section{A. Praktik Adat Nyowok di Desa Sokong Kecamatan Tanjung Kabupaten Lombok Utara}

Praktik adat nyowok yang dilakukan di Desa Sokong apabila seseorang melakukan pernikahan pada bulan Ramadan dan 6 hari pada Syawal, pasangan tersebut dikatakan sebagai pelanggar yang harus mengeluarkan denda berupa binatang berkaki empat seperti unta, kerbau, sapi atau kambing sesuai

22 Imam Mohtar, Problematika Pembinaan Pendidikan Agama Islam Pada Masyarakat (Sidoarjo: Uwais Inspirasi Indonesia, 2017), 19.

23 Andri (Pelaku Nyowok), Wawancara, Dusun dengan pelanggaran yang dilakukan. Selain itu, masyarakat yang melangsungkan pernikahan pada bulan terlarang bagi masyarakat Desa Sokong hendaknya mengikuti beberapa rangkaian proses adat selanjutnya. Setiap masyarakat yang melangsungkan pernikahan pada bulan Ramadan dan 6 hari pada bulan Syawal diberlakukan sama, atau dengan kata lain tidak ada yang membedakan proses adat dalam penerapannya baik pada bulan Ramadan maupun 6 hari pada Syawal. Sehingga dalam adat tersebut tetap dilakukan sesuai ketentuan yang telah ditetapkan oleh para tokoh adat. Semua proses dilakukan bagi masyarakat yang melanggar aturan sehingga masyarakat Desa Sokong tetap melakukan adat tersebut.

Berkaitan dengan hal tersebut maka peneliti menguraikan terlebih dahulu alasan masyarakat menikah di bulan terlarang sehingga terkena adat nyowok, proses adat nyowok.

1. Alasan masyarakat menikah pada bulan Ramadan dan 6 hari pada bulan Syawal

Alasan yang melatarbelakangi masyarakat Desa Sokong melakukan pelanggaran adat disebabkan oleh beberapa hal di antaranya:

a. Hamil sebelum perkawinan ${ }^{23}$.

Pernikahan merupakan suatu kodrat manusia yang tak bisa manusia hindari dan merupakan ikatan yang suci, namun ada kalanya pernikahan itu dilakukan dengan sebab-sebab tertentu. Sehingga dalam aturan adat yang tetap hidup sampai saat ini di Desa Sokong melarang melaksanakan perkawinan di bulan Ramadan dan 6 hari pada bulan Syawal dengan alasan untuk menghargai bulan yang mulia dan menghindari terjadinya percampuran antara suami istri pada siang hari. Namun masyarakat di Desa Sokong masih ada yang melanggar aturan tersebut disebabkan rusaknya pergaulan yang mengakibatkan terjadinya hamil di luar nikah dan mengharuskan ia menikah pada bulan tersebut.

b. Terlambat Pulang ${ }^{24}$

Aturan adat di Desa Sokong sangat banyak sehingga aturan tentang sampai kapan seseorang bisa pergi dan pulang pun diatur. Aturan yang dibuat di Desa Sokong sangat kental dan hidup di masyarakat. Alasan yang membuat masyarakat juga menikah pada bulan Ramadan dan 6 hari pada bulan Syawal disebabkan dengan pelanggaran terhadap adat yang selain adat nyowok yaitu pulang terlambat dengan seseorang yang tidak sejenis yang belum menikah. Seperti pulang pada waktu magrib.

Murjemeneng Desa Sokong, 10 Februari 2018

24 Abdullah (Masyarakat), Wawancara, Dusun Kencong Desa Sokong, 12 Februari 2018 


\section{Alasan Adanya adat Nyowok}

Adapun alasan yang melatarbelakangi adanya adat nyowok disebabkan karena sering terjadinya pelanggaran terhadap agama, di antaranya:

\section{a. Menghindari Percampuran pada Siang Hari atau Perzinaan}

Alasan utama yang membuat para tokoh adat membuat aturan berupa memberikan denda pada orang yang menikah pada bulan Ramadan dan Syawal adalah untuk menghindari percampuran pada siang hari atau perzinaan dalam pemahaman tokoh adat. Karena masyarakat Sokong masih awam dengan ilmu agama sehingga yang ditakutkan oleh pemuka adat apabila bulan Ramadan dan 6 hari Syawal disamakan dengan bulan lain yang memperbolehkan seseorang yang melakukan percampuran antara suami istri pada siang harinya sebagaimana pemaparan bapak Artep:

"kalau kita melihat masyarakat Sokong yang masih awam dengan pemahaman agama, itulah yang ditakutkan oleh para tokoh adat, yang melakukan sesuatu yang dilarang dalam ajaran agama seperti melakukan percampuran pada siang hari. Bulan Ramadan dan Syawal merupakan serangkaian bulan yang suci. Itulah alasan kenapa tokoh adat mengikutkan bulan Syawal juga. Pada bulan itu juga ada orang puasa sunah enam hari, itulah yang harus dihargai. Bulan Syawal memang sama dengan bulan yang lain, tetapi bulan Syawal itu termasuk serangkaian dengan bulan Ramadan, menurut pemahaman kami sehingga kami membuat aturan seperti itu). ${ }^{25}$

b. Menghindari Perkelahian

Alasan lain yang selain menghindari perzinaan yaitu menghindari perkelahian. Perkelahian yang terjadi di Desa Sokong yang di sebabkan oleh pernikahan merupakan juga alasan para tokoh adat membuat aturan tersebut. Karena dalam perkelahian yang mereka lakukan tidak hanya lewat mulut saja melainkan kekuatan fisik pun ikut serta. Bagi masyarakat desa Sokong perkelahian yang terjadi ketika bulan Ramadan dan 6 hari pada bulan Syawal sama halnya tidak berpuasa karena dalam Islam sendiri seseorang tidak hanya menahan lapar dan dahaga saja melainkan juga menjaga sesuatu yang membatalkan puasa, baik percekcokan dan perkelahian.

Sebagaimana pemaparan bapak Ahmad:

"siapa pun yang menikah pada bulan

25 Artep (Tokoh Adat), Wawancara, Dusun Mengkudu Desa Sokong, 03 Maret 2018

26 Ahmad (Tokoh Adat), Wawancara, Dusun Pengembuk Desa Sokong, 9 Maret 2018
Ramadan dan Syawal sering kali terjadinya perkelahian bahkan sampai-sampai mau saling membunuh. Sedangkan bulan Ramadan dan Syawal sangat-sangat dihormati, agar jangan berpuasa hanya sekedar menahan lapar dan dahaga saja ${ }^{26}$.

\section{Proses Adat Nyowok}

Penerapan adat nyowok tersebut disebabkan pelanggaran yang mereka lakukan sehingga dari tuntutan adat dan masyarakat terhadap pelaku yang melakukan pernikahan pada bulan Ramadan dan 6 hari pada bulan Syawal harus membayar denda. Sebelum membayar denda maka ada proses yang harus dilalui oleh ketua dan tokoh adat serta masyarakat yang melanggar aturan adat di antaranya:

a. Pemanggilan ${ }^{27}$

Pemanggilan yang dilakukan oleh ketua adat merupakan serangkaian proses yang ada dalam adat nyowok guna untuk memberitahukan kepada pihak yang melakukan pelanggaran berupa menikah pada bulan Ramadan dan 6 hari pada bulan Syawal. Proses pemanggilan yang dilakukan oleh ketua adat dengan cara mengirim utusan atau ketua adat sendiri yang langsung menemui orang yang melanggar adat. Pemanggilan yang dilakukan dengan lisan, apabila dalam pemanggilan pertama tokoh adat tidak menemui si pelanggar maka tokoh adat atau ketua adat turun langsung untuk pemanggilan tersebut sampai menemukan si pelanggar

b. Musyawarah atau Sidang Adat ${ }^{28}$

Musyawarah merupakan suatu cara untuk menyelesaikan permasalahan sehingga mendapatkan hasil sesuai dengan kesepakatan. Musyawarah yang dilakukan antara tokoh adat dengan orang yang melakukan pelanggaran mengenai pembayaran denda serta waktu pelaksanaan denda. Dalam musyawarah ketua adat tidak memaksa para pihak antara melakukan adat nyowok atau tidak. Apabila si pelanggar tidak melakukan adat nyowok tersebut maka si pelanggar akan diabaikan atau tidak diurus oleh masyarakat mengenai keperluan-keperluan adat yang lain. Seperti apabila meninggal dunia maka masyarakat hanya memandikan, mengafankan, menyalatkan dan menguburkan. Setelah itu tidak akan diurus lagi mengenai adatnya, seperti merayakan hari ketujuh (memituq, kesembilan (menyiwaq)) orang meninggal menurut adat Desa Sokong.

c. Pengumuman

27 Rahmat Suryadi (Ketua Adat), Wawancara, Dusun Kencong Desa Sokong, 17 Februari 2018

28 Latif (Tokoh Adat), Wawancara, Dusun Mengkudu Desa Sokong, 18 Februari 2018 
Setelah mengikuti beberapa proses, di antaranya pemanggilan dan musyawarah, maka proses selanjutnya pengumuman, di mana para tokoh adat dan masyarakat yang bersangkutan yang sudah menemukan kesepakatan, maka selanjutnya tokoh adat membuat pengumuman yang ditunjukkan kepada masyarakat dusun tersebut. yang pengumumannya berisi tentang kesanggupan pihak yang bersangkutan untuk membayar denda yang sudah ditentukan dan ketentuan hari untuk melangsungkan adat tersebut.

\section{d. Pelaksanaan}

Apabila semua proses dalam praktik adat nyowok sudah dilaksanakan, maka tahap terakhir yang harus dilakukan yaitu tahap pelaksanaan acara adat nyowok. Di mana dalam tahap pelaksanaan yang dilakukan para pihak untuk membayar denda sesuai dengan ketentuan yang sudah ada dalam awik-awik Desa Sokong.

Sebelum acara pelaksanaan adat nyowok dimulai maka para pelanggar menyerahkan beberapa perlengkapan yang dibutuhkan dalam pelaksanaan adat nyowok tersebut di antaranya.

1) Menyerahkan Seekor Kambing

Rangkaian praktik adat nyowok di Desa Sokong yaitu seseorang yang melanggar adat berupa menikah pada bulan Ramadan dan 6 hari pada bulan Syawal maka harus mengorbankan atau menyerahkan seekor kambing untuk disembelih. Penyembelihan kambing tersebut dilakukan di luar masjid, kemudian kambing itu dimasak terlebih dahulu setelah itu barulah dibagikan kepada fakir

2) Membuat 40 Ancak, 4 Dulang, Tumbek Pituk dan 7 Kekatik

Ancak adalah sebuah anyaman yang terbuat dari bambu yang berbentuk segi empat, selain menyembelih kambing seorang yang menikah pada bulan Ramadan dan Syawal harus membuat 40 ancak dan 4 dulang. Bagi orang yang melanggar adat harus mengumpulkan fakir miskin sebanyak 40 kemudian memberikan satu ancak untuk satu orang yang berisi nasi dan daging kambing yang telah dimasak. Selain itu si pelanggar juga menyiapkan 4 dulang untuk para tokoh agama yang ikut serta dalam menyelesaikan adat nyowok tersebut. Makna dari 40 ancak yaitu orang yang bisa melakukan Shalat Jumat sekurang- kurangnya 40 orang. Dan makna 4 dulang dilihat dari para petugas yang melakukan Shalat Jumat seperti 1 imam, 1 khatib, 1 muazin pertama dan 1 mu'adzin dan mu'adzin kedua. Selain menyiapkan 40 ancak dan 4 dulang, di dalam ancak tersebut juga harus ada 7 kekatik atau 7 sapu lidi yang dipotong dan tumbek pituk atau 7 pisau. Arti dalam 7 kekatik dan tumbek pituk menurut kepercayaan tokoh adat yaitu langit itu memiliki 7 lapis dan bumi juga memiliki 7 lapis.

\section{3) Bedak Langeh}

Bedak Langeh adalah keramas dengan menggunakan kelapa yang diparut namun dalam adat nyowok tidak diartikan demikian karena dalam adat nyowok seseorang hanya diberi sindur. Adapun bahan dari pembuatan sindur adalah kelapa, bedak kuning yang terbuat dari beras yang ditumbuk bercampur dengan kunyit dan darah ternak yang dipotong kemudian diaduk. Makna dari bedak langeh menurut kepercayaan masyarakat adat Desa Sokong yaitu percampuran warna putih (kelapa) dengan merah (darah daging ternak) maka akan menjadi kuning (beras bercampur kunyit), apabila tiga warna ini bercampur maka akan menghasilkan warna kekuningan. Itu dilakukan di dalam masjid oleh pemangku adat

4) Zikir

Setelah ritual yang dilakukan maka acara terakhir yang dilakukan di dalam masjid yaitu zikir sebagai penutup acara tersebut yang dipimpin oleh kiainya. Kemudian memulai memakan santapan yang sudah disiapkan berupa ancak dan dulang yang berisi daging kambing dan nasi.

\section{Pandangan Tokoh Agama terhadap Adat Nyowok}

Pelaksanaan praktik adat nyowok memiliki tata cara atau aturan sesuai dengan ketentuan adat yang disepakati pemberlakuannya. Menurut hasil penelitian ini menunjukkan bahwa praktik nyowok ini tidak berlaku bagi semua kalangan masyarakat suku Sasak yang ada di Lombok. Karena berlakunya bersifat tidak menyeluruh maka aturan dan cara kerjanya sesuai dengan praktik setempat, seperti praktik nyowok yang berlaku bagi masyarakat Desa Sokong tentu tata caranya sesuai dengan adat yang berlaku di kalangan masyarakat Desa Sokong.

Dalam pandangan tokoh agama memandang adat ini dari dua sudut pandang di antaranya: pertama, adat ini berlaku sejak lama dan berlaku serta diyakini bagi masyarakat terdahulu. Kedua, masyarakat Sokong sekarang lebih mendalami agama dibandingkan adatnya. Adat memang merupakan kebiasaan yang hidup di masyarakat, serta di dalam adat tersebut ada nilai agama, namun dalam praktiknya tidak mencerminkan nilai agama seperti bedak langeh atau memberikan sindur dengan darah kambing di dalam masjid. Sedangkan masjid itu tempat ibadah. Perlu juga diperhatikan bahwa kehidupan masyarakat sekarang. Sebagaimana pendapat ustaz Tahir:

"adat yang hidup di Desa Sokong memang sudah lama dan bahkan tidak mudah untuk tidak memberlakukannya kembali. Adat tersebut memiliki nilai agama, namun dalam praktik pelaksanaannya tidak sesuai dengan syariat. Banyak masyarakat yang melanggar 
larangan tersebut karena mereka paham mana yang lebih baik bagi mereka. Karena dalam kaidah berbunyi menghilangkan kemudaratan itu lebih didahulukan dari pada mengambil sebuah kemaslahatan, dalam arti bahwa adat tersebut harus melihat dengan dilarangnya pernikahan pada bulan tersebut maka seseorang bisa melakukan sesuatu yang dilarang oleh agama, bagi kita adat itu baik namun akan menjadi buruk dengan tetapnya diberlakukan adat tersebut dan mengakibatkan banyaknya yang melanggar akan syiat Islam”29.

\section{B. Tinjauan Hak Asasi Manusia terhadap Adat Nyowok}

Di Indonesia, komunitas masyarakat yang masih memegang teguh aturan atau norma adat yang salah satu istilahnya ialah masyarakat hukum adat masih menjadi bagian dari masyarakat yang paling rentan dalam hal pemenuhan hak-haknya. Di dalam sejarah bahkan sebelum terbentuknya Republik Indonesia, masyarakat hukum adat sering kali mendapat perlakukan diskriminasi dan marginalisasi. Perlakuan diskriminasi dapat dilihat dari berbagai kebijakan yang hadir masih belum menjunjung tinggi perlindungan dan penghormatan hak masyarakat hukum adat. Persoalan yang terjadi sering kali karena adanya upaya pembangunan yang dilaksanakan oleh pemerintah hanya didasarkan pada kebijakan sepihak semata dan tidak pernah mengikutsertakan masyarakat hukum adat dalam tiap tahapan pembuatan kebijakan tersebut. Akibatnya, masyarakat hukum adat hanya dianggap sebagai obyek dalam tiap kebijakan sehingga terjadinya penindasan, kekerasan, kriminalisasi dan bahkan perampasan hak-hak masyarakat hukum adat. $^{30}$

Keberadaan Undang-Undang Nomor 39 Tahun 1999 tentang Hak Asasi Manusia merupakan barometer akan kemampuan pemerintah dalam menyelenggarakan roda berbangsa bernegara yang berlandaskan hak asasi manusia. Masih di dalam Undang-Undang Nomor 39 Tahun 1999 tentang Hak Asasi Manusia, pada bagian menimbang huruf d tertulis, "bahwa bangsa Indonesia sebagai anggota Perserikatan Bangsa-Bangsa mengemban tanggung jawab moral dan hukum untuk menjunjung tinggi

29 Tahir (Tokoh Agama), Wawancara, Dusun Kencong Desa Sokong, 8 April 2018

30 Frichy Ndaumanu, "Kebijakan Pemerintah Daerah Terhadap Upaya Perlindungan Dan Penghormatan Masyarakat Hukum Adat Di Kabupaten Alor Provinsi Nusa Tenggara Timur,” Jurnal HAM Volume 9 (2018): 38.

31 Victorio H. Situmorang, “Kebebasan Beragama dan melaksanakan Deklarasi Universal tentang Hak Asasi Manusia yang ditetapkan oleh Perserikatan Bangsa-Bangsa, serta berbagai instrumen internasional lainnya mengenai hak asasi manusia yang telah diterima oleh negara Republik Indonesia”. Beberapa hal tersebut merupakan bentuk keseriusan lainnya dari pemerintah Indonesia, bahwa hak asasi manusia hadir dalam kehidupan berbangsa dan bernegara di Indonesia. Namun tentunya tidak akan cukup sampai di tataran peraturan saja, tanpa implementasi konkret di lapangan ${ }^{31}$.

Perkawinan yang termuat dalam UndangUndang Nomor 1 Tahun 1974 Pasal 1 yang menyatakan perkawinan adalah ikatan lahir batin antara seorang pria dengan wanita sebagai suami istri dengan tujuan membentuk keluarga yang bahagia dan kekal berdasarkan Ketuhanan Yang Maha Esa ${ }^{32}$.

Perkawinan menurut HAM yaitu peristiwa yang sangat penting dalam kehidupan manusia. Dengan terjalinnya pernikahan akan melahirkan keturunan yang merupakan dasar terbentuknya sebuah keluarga dan terbentuknya sebuah negara dan bangsa ${ }^{33}$. Mengingat pentingnya peran hidup bersama, pengaturan mengenai perkawinan memang harus dilakukan oleh negara, di sini negara berperan untuk melegalkan hubungan hukum antara seorang pria dan seorang wanita.

Adat adalah suatu yang diyakini mayoritas orang, baik berupa ucapan atau perbuatan yang sudah berulang-ulang sehingga tertanam dalam jiwa dan diterima oleh akal mereka ${ }^{34}$.

Berdasarkan sifatnya yang tidak tertulis, hukum adat memiliki peraturan hidup yang meskipun tidak ditetapkan dalam hukum formal tetapi ia tetap menjadi hukum yang ditaati dan didukung oleh rakyat dengan segenap keyakinan mereka bahwasanya peraturan tersebut memiliki kekuatan hukum.

Adapun unsur-unsur hukum adat di antaranya:

a. Adanya tingkah laku yang dilakukan secara terus menerus

b. Adanya pola tingkah laku yang sistematis dan teratur

Sebagai Bagian Dari Hak Asasi Manusia,” Jurnal HAM Volume 10 (2019): 64.

32 Beni Ahmad Saebani, Fiqh Munakahat (Bandung: Pusataka Setia, 2009), 15.

33 Soedhar Soimin, Hukum Orang Dan Keluarga, revisi edi. (Jakarta: Sinar Grafika, 2002), 3.

34 Rasyad Hasan Khalil, Tarikh Tasyri' (Jakarta: Amzah, 2011), 167. 
c. Adanya nilai sakral yang dipakai dalam tingkah laku tersebut

d. Adanya keputusan kepala adat

e. Adanya akibat hukum/sanksi

f. Tidak tertulis

g. Ditaati karena kepatutan dan kewibawaannya ${ }^{35}$.

Perkembangan HAM di Indonesia secara yuridis turut dicampuri oleh dunia Hukum Internasional. Sudah menjadi suatu konsekuensi logis, bahwa kemerdekaan Indonesia yang bermula dari penjajahan berabad-abad menghasilkan sikap nasionalis untuk mempertahankan hak atas rakyatnya. Di samping itu pengaruh doktrin barat atas HAM turut mengambil peran, hingga menghasilkan dasar negara Indonesia, yaitu UUD 1945 yang dalam pembukaannya mengakui eksistensi HAM secara eksplisit ${ }^{36}$.

Indonesia kemudian meratifikasi piagam Perserikatan Bangsa-Bangsa sebagai sebuah undang-undang yang sah berlaku di Indonesia. Ratifikasi tersebut diwujudkan dalam UndangUndang Nomor 39 Tahun 1999. Ratifikasi ini dilakukan utamanya bukan karena Indonesia merupakan anggota PBB kala itu, melainkan terungkapnya beberapa kasus pelanggaran HAM berat saat pemerintahan Soeharto ${ }^{37}$.

Secara umum HAM di Indonesia meliputi hak untuk hidup, hak berkeluarga, dan melanjutkan keturunan, hak mengembangkan diri, hak memperoleh keadilan, hak atas kebebasan pribadi (memilih dan mempunyai keyakinan politik, mengeluarkan pendapat di muka umum, memeluk agama masing-masing. Tidak boleh diperbudak, memilih kewarganegaraan tanpa diskriminasi, bebas bergerak, berpindah dan bertempat tinggal di wilayah Republik Indonesia), hak atas rasa aman,

35 A.Suriyaman Mustari Pide, Hukum Adat (Jakarta: Prenamedia Group, 2014), 8.

36 Undang-Undang Dasar RI Tahun 1945 (Surakarta: Pustaka Mandiri), 4.

37 “Kodifikasi UU No. 39 Tahun 1999,” last modified 2019,

http://dkyusupblogspot.com/2008/04/Kodifikasi-UuNo-39-Tahun-1999.Html.

38 Dalam UDHR Pasal 6 Dinyatakan: Men And Women Of Full Age Without Any Limitation Due To Rice, Nationality, Or Religion, Have The Right To Marry And To Found A Family. The Are Entitled To Equa Right To Marriage, During Marriage And At Its Dissolution. Pasal Tersebut Menyatakan Bahwa Setiap Laki-Laki Dan Perempuan Mempunyai Hak Untuk Menikah Dan Membangun Keluarganya Tanpa Halangan Adanya Perbedaan Ras, Kebangsaan Atau Kewarganegaraan Dan Perbedaan Agama. Pasal

7 GHR Bahwa Perbedaan Agama, Bangsa Dan Atau hak atas kesejahteraan, hak turut serta dalam pemerintahan, hak wanita dan hak anak ${ }^{38}$.

Undang-Undang Nomor 39 Tahun 1999 tentang HAM di Indonesia terdapat penjelasan tentang kebebasan untuk menikah dan meneruskan keturunan, sebagaimana dinyatakan dalam Pasal 10 Ayat (1) ${ }^{39}$. Dalam Pasal 2 UU perkawinan, perkawinan yang sah yaitu perkawinan yang dilakukan berdasarkan agama dan kepercayaan masing-masing.

Sedangkan jika dilihat dari HAM dalam Islam teosentris, artinya segala sesuatu berpusat kepada Tuhan. Pandangan Islam bahwa Tuhan sangat dipentingkan A.K Brohi menyatakan pendekatan Islam berbeda dengan pendekatan Barat. Di mana strategi Islam sangat mementingkan penghargaan kepada hak-hak asasi dan kemerdekaan dasar manusia sebagai sebuah aspek kualitas dari kesadaran keagamaan yang terpatri di dalam hati, pikiran, dan jiwa penganutnya ${ }^{40}$.

Hubungan antara Islam dan hak asasi manusia, terletak pada universalitas ajaran Islam. Universalitas hak asasi manusia telah digaransi di dalam prinsip-prinsip dasar hukum Islam yang berasal dari teks-teks suci maupun konstruksi pemikiran ulama ${ }^{41}$.

Adapun telah menjadi consensus bahwa tatanan global harus ditegakkan di atas kepentingan perdamaian dunia. Pasca perang dunia II, masyarakat internasional jatuh pada kesimpulan untuk segera mengambil langkah-langkah strategis dalam mengusung dunia yang lebih beradab. Manfred menegaskan, sekalipun Deklarasi Universal Hak Asasi Manusia (DUHAM) diakui sebagai hukum Internasional yang tidak mengikat,

Asal Sama Sekali Bukanlah Menjadi Halangan Untuk Perkawinan

39 Pasal 10 Ayat UU Nomor 39 Tahun 1999 Berbunyi Setiap Orang Berhak Untuk Membentuk Suatu Keluarga Dan Melanjutkan Keturunan Melalui Melalui Perkawinan Yang Sah. Akan Tetapi Dalam Ayat Selanjutnya Dinyatakan Bahwa Perkawinan Yang Ditentukan Menurut UU.

40 Menurut A.K Brohi Menyatakan Pendekatan Islam Berbeda Dengan Pendekatan Barat. Di mana Strategi Islam Sangat Mementingkan Penghargaan Kepada Hak-Hak Asasi Dan Kemerdekaan Dasar Manusia Sebagai Sebuah Aspek Kualitas Dari Kesadaran Keagamaan Yang Terpatri Di Dalam Hati, Pikiran, Dan Jiwa Penganutnya

41 Candra Perb, "Penegakan Hak Asasi Manusia Di Era Globalisasi Dalam Perspektif Hukum Islam,” AlAdalah Vol.12 (2015): 850. 
namun DUHAM merupakan penafsiran otoritatif tentang istilah HAM dan piagam PBB. ${ }^{42}$

Sesuai dengan pembabakan di atas, pemaparan berikut akan dimulai dengan pembahasan periode pertama. Pada menyusun konstitusi, Undang-Undang Dasar 1945, terjadi perdebatan mengenai apakah hak warga negara perlu dicantumkan dalam Pasal-Pasal UndangUndang Dasar. Soekarno dan Supomo mengajukan pendapat bahwa hak-hak warga negara tidak perlu dicantumkan dalam Pasal-Pasal konstitusi. ${ }^{43}$

Berdasarkan penjelasan di atas maka diatur pula dalam hak asasi manusia tentang kebebasan pribadi di mana setiap orang berhak untuk melakukan suatu tanpa terikat oleh adat atau kebiasaan masyarakat terdahulu dan tidak diragukan lagi bahwa kebebasan pribadi merupakan pokok dari kebebasan-kebebasan asasi, karena kebebasan pribadi berhubungan dengan diri manusia dan kemuliaannya. Maka kebebasan pribadi dan hal-hal yang berhubungan dengannya merupakan asas kehidupan manusia dan sumber nilainya sebagai manusia atau sebagai individu dan merupakan sebab kemajuannya menuju cita-cita kemanusiaan yang tertinggi ${ }^{44}$.

Pemahaman tentang HAM juga harus di lakukan dalam konteks manusia sebagai makhluk sosial, di mana dalam kehidupannya, manusia yang selalu berhubungan dengan manusia yang lain. Sebagaimana di tentukan dalam Pasal 1 Universal Declaration of Human Right, bahwa manusia hendaknya bergaul dalam suasana persaudaraan, memberi makan bahwa manusia yang satu harus menghormati dan menghargai manusia yang lain. HAM tidaklah bersifat absolut, artinya kebebasan dan HAM yang satu akan dibatasi oleh kebebasan dan HAM lain ${ }^{45}$.

Undang-Undang Dasar Negara Republik Indonesia Pasal 28 E Ayat (1) dan Pasal 29 Ayat (2) dengan tegas menjamin adanya kebebasan menjalankan agama dan kepercayaan yang dianut oleh setiap orang. Kebebasan ini pada dasarnya juga berarti bahwa negara tidak turut campur dalam masalah-masalah agama. Secara filosofis, pengaturan seperti ini tidak sesuai dengan cita-cita

42 Majda El Muhtaj, Dimensi-Dimensi HAM Mengurai Hak Ekonomi, Sosial, Dan Budaya (Jakarta: Rajawali Pers, 2009), 80.

43 Njal Hostmaelingen Rhona K.M. Smith, Hak Asasi Manusia (Yogyakarta: Pusham UII, 2008), 238.

44 Subhi Mahmassani, Konsep Dasar Hak-Hak Asasi Manusia (Jakarta: : PT. Tintamas Indonesia, 1979), 73.

45 Hesti Armiwulan Sochmawardia, Diskriminasi penegakan Hak Asasi Manusia di Indonesia. Pengaturan mengenai hak-hak dasar dalam bidang perkawinan tidak diselaraskan dengan peraturan perundang-undangan lainnya.

Undang-Undang Hak Asasi Manusia Pasal 10 Ayat (2) 46 secara tegas menyatakan bahwa perkawinan yang sah hanya dapat dilakukan atas kehendak bebas dari kedua pihak. Dalam hal ini prinsip atas asas utama dilakukannya perkawinan yang sah adalah kehendak bebas dari kedua pihak. Dalam penjelasan Pasal 10 Ayat (2) UndangUndang Hak Asasi Manusia, yang dimaksud, dengan kehendak bebas adalah kehendak yang lahir dari niat yang suci tanpa paksaan, penipuan, atau tekanan apa pun dan dari siapa pun terhadap calon suami dan/atau calon istri. Dari sini dapat disimpulkan bahwa perkawinan menurut UndangUndang Hak Asasi Manusia hanya dipandang dari aspek keperdataan saja. Tidak ada unsur bulan sebagai syarat sahnya perkawinan.

Menurut penulis sama halnya dengan kehidupan masyarakat adat yang hendak melakukan perkawinan ada tradisi tertentu yang harus dan tidak boleh dilakukan dalam wilayah adat tersebut. Dan tradisi tersebut dipercayai oleh sebagian besar masyarakat dan kemudian menjadi budaya. Namun dalam budaya yang baik hendaknya memperhatikan hal yang penting guna tidak menjadikan mudarat kepada masyarakat adat sehingga dengan kebudayaan yang hidup dan berkembang tentang tidak bolehnya masyarakat menikah pada bulan Ramadan dan Syawal bisa mendatangkan mudarat lebih banyak dari pada manfaat, di mana agama diduakan dengan adat. Walaupun di dalamnya ada nilai agama, namun lebih banyak mudaratnya.

Adat nyowok memiliki dampak positif karena terkandung unsur agama di dalamnya namun perlu diperhatikan, perkembangan zaman menuntut masyarakat lebih memahami kebutuhan dirinya dibandingkan dengan adat tersebut. Karena sebagian orang tidak mengikuti adat. Sebagaimana orang melangsungkan pernikahan tanpa memperhatikan adat yang mengatur masyarakat tersebut dan mengutamakan hukum Islam sebagai pedoman dasarnya.

Rasial Dalam Hukum HAM (Yogyakarta: Genta, 2013), 51.

46 Pasal 10 Ayat (2) Undang-Undang Hak Asasi Manusia Menjelaskan Bahwa Perkawinan Yang Sah Adalah Perkawinan Yang Dilakukan Atas Kehendak Bebas Dari Kedua Pihak. Artinya Perinsip Utama Dilakukan Dlama Perkawinan Yang Sah Adalah Kehendak Bebas Dari Kedua Pihak. 
Sebagaimana pemaparan Budianto: "namanya jodoh apa hendak dikata, kalau menikahmenikah sudah. Bagaimanapun banyaknya aturan yang dibuat, kalau seseorang ingin menikah ia menikah, tidak peduli dengan aturan yang dibuat. Islam pun menganjurkan seseorang untuk menikah makanya seseorang menikah, seandainya Islam melarang maka tidak ada yang mengisi bumi ini" ${ }^{47}$.

Sebagian orang juga sudah tahu aturan adat namun ia melanggarnya meskipun harus membayar denda karena menikah merupakan hal yang baik, daripada harus melakukan sesuatu yang dilanggar oleh Islam sebagaimana pendapat Melta: "sebelum saya menikah, saya sudah tahu aturan yang ada di Desa Sokong itu, tetapi saya tetap menikah pada bulan Ramadan. Walaupun harus membayar denda, sebab menurut saya menikah itu bagus, dari pada saya melakukan sesuatu yang keluar dari ajaran Islam lebih baik saya menikah. Dan dulu saya tidak dipaksa untuk menikah melainkan atas kehendak sendiri. Adat tersebut dapat merugikan masyarakat, karena tingkat ekonomi masyarakat Desa Sokong sangat lemah. Melihat dari pergaulan masyarakat Desa Sokong saat ini berbeda dengan yang terdahulu di mana anak muda lebih bebas dan tak takut melakukan sesuatu yang dilarang, maka salah satu cara untuk menyelamatkan anak muda dari pergaulan yaitu menikah. Adat sudah tidak berlaku lagi bagi masyarakat saat ini" ${ }^{48}$.

Guna melakukan penegakan HAM terdapat unsur pendukung lain, yang sangat erat kaitannya dengan penegakan HAM di era globalisasi, yakni budaya hukum ${ }^{49}$. Budaya (kultur) hukum merupakan salah satu unsur penting yang ada dalam rangka penegakan hukum selain struktur substansi hukum. Struktur hukum terkait dengan penegakan hukum, seperti: pengadilan, kejaksaan, kepolisian, dan lembaga pemasyarakatan sebagai perwujudan sistem peradilan pidana yang integral. Substansi hukum merupakan produk hukum berupa aturanaturan yang aktual, norma, dan perilaku dari orangorang dalam suatu sistem. Sedangkan kultur hukum merupakan perilaku orang terhadap hukum dan

47 Budianto, Wawancara, Pengembuk, 07 Maret 2018

48 Melta, Wawancara, Kencong, 03 Maret 2018

49 Ed.Al Ifdhal Kasim, Eddie Riyadi Terre, Kebenaran Versus Keadilan, Pertanggungjawaban Pelanggaran HAM Di Masa Lalu, ELSAM (Jakarta: Lembaga Studi Dan Advokasi Masyarakat, 2003), 9.

50 Badaruddin Lopa, Pertumbuhan Demokrasi Penegak Hukum Dan Perlindungan Hak Asasi Manusia (Jakarta: PT Yarsif Wa, 1999), 53.

51 Satjipto Rahardjo, Ilmu Hukum, Pencarian, Pembebasan Dan Pencerahan (Surakarta: Muhammadiyah University Press, 2004), 77. sistem hukum iklim dari pemikiran sosial dan kekuatan sosial yang menentukan bagaimana hukum digunakan, dihindari, atau disalahgunakan ${ }^{50}$.

Oleh karena itu, budaya hukum perlu ditumbuhkan dalam masyarakat, karena tanpa budaya hukum akan mudah terjadi pelanggaran hukum di dalam masyarakat. Peranan penting dalam budaya hukum ialah sebagai penggerak bekerjanya hukum $^{51}$.

Dalam kaitannya dengan penegakan HAM, budaya hukum merupakan sarana kontrol terhadap aturan-aturan dan lembaga-lembaga yang terkait dengan penegakan HAM. Ini penting artinya, agar aturan-aturan tentang perlindungan HAM yang ada dapat dijalankan untuk mencegah terjadinya pelanggaran HAM berat yang bertentangan dengan nilai-nilai kemanusiaan terlebih lagi di era globalisasi ${ }^{52}$.

Berbicara mengenai hukum di mana Pengakuan hukum terhadap masyarakat adat di Indonesia, sejak fase kemerdekaan sampai saat ini telah mengalami 4 fase pengakuan, Pertama; setelah Indonesia merdeka tahun 1945, pendiri negara ini telah merumuskan dalam konstitusi negara (UUD 1945) mengenai pengakuan terhadap masyarakat adat. Di dalam UUD 1945 dikatakan bahwa di Indonesia terdapat sekitar 250 daerah-daerah dengan susunan asli (zeljbesturende, volksgemeenschappen), seperti marga, desa, dusun dan nagari, hal ini merupakan bentuk pengakuan dari UUD 1945 yang tidak terdapat dalam konstitusi-konstitusi yang pernah berlaku di Indonesia seperti Undang-Undang Dasar Republik Indonesia Serikat dan Undang-Undang Dasar Sementara ${ }^{53}$.

Kedua; pengakuan hukum terhadap masyarakat hukum adat terjadi pada tahun 1960 dengan diundangkannya Undang-Undang No.5 Tahun 1960 Tentang Undang-Undang Pokok Agraria (UUPA) ${ }^{54}$. Pengakuan terhadap masyarakat hukum adat dan hak ulayat dilakukan sepanjang menurut kenyataan masih eksis serta sesuai dengan kepentingan nasional dan selaras dengan

52 H. Muladi, Hak Asasi Manusia, Hakekat, Konsep Dan Implikasinya Dalam Perspektif Hukum Dan Masyarakat (Bandung: PT Refika Aditama, 2005), 57-58.

53 Teddy Anggoro, "Kajian Hukum Masy Arakat Hukum Adat Dan Ham Dalam Llngkup Negara Kesatuan Republik Indonesia,” Jurnal Hukum Dan Pembangunan Vol. 36 (2006): 490.

54 "Undang-Undang Republik Indonesia Nomor 5 Tahun 1960 Tentang Peraturan Dasar Pokok-Pokok Agraria,” 1960. 
perundang-undangan di atasnya. Konsep pengakuan dalam UUPA berbeda dengan konsep pengakuan dalam UUD 1945 karena konsep pengakuan dalam UUPA adalah konsep pengakuan bersyarat.

Ketiga; pada awal rezim orde baru dilakukan legislasi terhadap beberapa bidang yang terkait erat dengan Masyarakat Hukum Adat dan Hak-haknya atas tanah seperti, Undang-Undang No. 5 Tahun 1967 tentang Kehutanan dan Undang-Undang No. 11 Tahun $1967^{55}$ tentang Pertambangan. Dalam kedua undang-undang ini mengatur pengakuan terhadap hak-hak Masyarakat Hukum Adat sepanjang masih ada yang kemudian pada perkembangannya setiap peraturan perundangundangan yang dilegislasi pada masa orde baru selalu mensyaratkan pengakuan apabila memenuhi unsur-unsur: (I) dalam kenyataan masih ada; (2) tidak bertentangan dengan kepentingan nasional; (3) tidak bertentangan dengan peraturan perundangundangan yang lebih tinggi; dan (4) ditetapkan dengan peraturan daerah, konsep ini dikenal dengan nama konsep pengakuan bersyarat berlapis. Yang intinya untuk diakui eksistensinya suatu. Masyarakat Hukum Adat harus memenuhi syarat sosiologis, politis, normatif yuridis dan prosedural (ditetapkan dengan Peraturan Daerah), dengan demikian pengakuan hukum tersebut tidak memberikan kebebasan bagi masyarakat adat melainkan memberikan batasan-batasan ${ }^{56}$.

Keempat; pasca reformasi UUD 1945 diamendemen, pada amendemen kedua tahun 2000 dihasilkan pengaturan pengakuan masyarakat hukum adat dan hak-haknya. Berdasarkan ketentuan Undang-Undang Dasar 1945 amendemen kedua, Pasal 18 B Ayat (2), TAP MPR Nomor XVII/MPR/1998 tentang Hak Asasi Manusia II. Piagam Hak Asasi Manusia 9, Undang-Undang Nomor 39. Tahun 1999 tentang Hak Asasi Manusia dan ketentuan undang-undang lain yang terkait, maka dapat ditarik benang merah bahwa pengakuan terhadap masyarakat hukum adat dan hak-hak tradisionalnya pada masa reformasi masih menerapkan pola pengakuan yang sama dengan orde baru yaitu pengakuan bersyarat berlapis ${ }^{57}$.

55 “Undang-Undang Republik Indonesia Nomor 11 Tahun 1967 Tentang Ketentuan-Ketentuan Pokok Pertambangan,” 1967.

56 Pengakuan Hukum Terhadap Masyarakat Indonesia Melalui Empat Fase. Pertama, Setelah Indonesia Merdeka Tahun 1945. Kedua, Pada Tahun 1960 Dengan Di Undangkannya Undang-Undang No. 5 Tahun 1960 Tentang Undang-Undang Pokok Agraria (UUPA). Ketiga, Pada Awal Rezim Orde Baru Dilakukan Legislasi Terhadap Beberapa Bidang Yang Terkait Erat Dengan Masyarakat Hukum Adat
Sebagai salah satu negara yang berdasarkan hukum Indonesia menganut prinsip perlindungan hak asasi manusia ${ }^{58}$. Berdasarkan Pasal 3 Ayat (3) Undang-Undang Hak Asasi Manusia, jaminan perlindungan atas hak asasi manusia ini diberikan tanpa melakukan diskriminasi.

Berdasarkan beberapa teori yang menggambarkan tentang adat dan hak asasi manusia, di mana dalam adat ini seseorang tidak boleh melakukan pernikahan pada bulan Ramadan dan Syawal yang mana apabila melakukan pernikahan pada bulan tersebut dikenakan denda berupa mengeluarkan hewan berkaki empat. Dan kalau di lihat dari perekonomian masyarakat tidak memiliki strata sosial yang tinggi sehingga tidak semua masyarakat dapat membayar denda. Ketika denda tidak dibayar maka konsekuensinya pernikahan tersebut dianggap tidak sah dan harus diasingkan dari tempat tinggalnya. Sedangkan menurut hak asasi manusia seseorang memiliki hak membina rumah tangga dan memiliki keturunan, tanpa melihat dari waktu. Dalam Undang-Undang Nomor 1 Tahun 1974 juga tidak mengatur tentang sahnya pernikahan karena waktu.

\section{KESIMPULAN}

Berdasarkan uraian di atas maka dapat mengambil kesimpulan. Pertama, terkait Praktik Adat Nyowok di Desa Sokong Kecamatan Tanjung Kabupaten Lombok Utara Perspektif Hak Asasi Manusia. Praktik adat nyowok terlebih dahulu dilakukan apabila seseorang menikah pada bulan Ramadan dan 6 hari pada bulan Syawal. Perkawinan bulan Ramadan dan Syawal yang dilakukan masyarakat Desa Sokong disebabkan beberapa hal: pertama, hamil di luar nikah. Kedua, terlambat pulang. Adat nyowok didahului dengan beberapa proses, di antaranya: pemanggilan para pihak, musyawarah atau sidang adat, memutuskan, pengumuman dan pelaksanaan. Di dalam pelaksanaannya seseorang harus menjalani beberapa hal di antaranya: seekor kambing, membuat ancak, bedak langeh dan zikir.

Dan Hak-Haknya Atas Tanah Seperti, UndangUndang No. 5 Tahun 1967 Tentang Kehutanan Dan Undang-Undang No. 11 Tahun 1966 Tentang Pertambangan. Keempat; Pasca Reformasi UUD 1945 Diamendemen, Pada Amendemen Kedua Tahun 2000 Dihasilkan Pengaturan Pengakuan Masyarakat Hukum Adat Dan Hak-Haknya

57 Ibid., Hal. 491

58 Maria Farida Indrati Soeprapto, Ilmu PerundangUndangan Dasar-Dasar Dan Pembentukannya, 11th ed. (Yogyakarta: Kanisius, 2006), 128. 
Kedua, menurut hak asasi manusia juga menyebutkan bahwa dalam Pasal 10 bahwa seseorang berhak membina rumah tangga dan memiliki keturunan. Hak asasi manusia juga memberikan Batasan bahwa perkawinan harus sesuai dengan peraturan perundang-undangan. Namun ketika dalam peraturan perundangundangan tidak mengatur maka seseorang boleh melangsungkan perkawinan berdasarkan hukum dan kepercayaan masing-masing. Adat nyowok tersebut tidak dikatakan bertentangan dengan hak asasi manusia jika tidak membuat kerugian pada masyarakat. Di mana komunitas adat nyowok di Desa Sokong sebagian besar merasa dirugikan dengan adanya adat nyowok tersebut. Sehingga adat nyowok tersebut akan menjadi pelanggaran hak asasi manusia jika memaksakan kehendak adat yang bisa bertentangan dengan hukum Islam. Di mana dalam hak asasi manusia juga mengatur tentang hak beragama.

\section{SARAN}

Bagi tokoh adat, untuk lebih mempertimbangkan terhadap larangan pernikahan pada bulan Ramadan dan Syawal tersebut, dikarenakan dalam hukum Islam, hukum negara tidak memberikan larangan terhadap seseorang yang hendak ingin melangsungkan pernikahan. Selain itu perlu diperhatikan denda yang diberikan agar tidak terlalu berat karena masyarakat juga tidak memiliki kemampuan yang sama dalam membayar denda, serta lebih melihat dampak yang terjadi di dalam masyarakat yang disebabkan dengan adanya adat tersebut.

Masyarakat Desa Sokong khususnya para tetua desa yang berpegang teguh pada adat, hendaknya lebih memperhatikan dampak yang ditimbulkan oleh satu adat bukan hanya semata untuk melestarikan adat. Akan tetapi jika mudaratnya lebih banyak sebagaimana pendapat para masyarakat tidak mampu melunasi denda dan kemudian diasingkan, bahkan melakukan perzinaan yang dilarang menurut agama sebaiknya ditiadakan. Namun apabila dengan adat itu memiliki dampak yang sangat baik barulah adat itu tetap dipertahankan.

\section{UCAPAN TERIMAKASIH}

Terima kasih saya ucapkan kepada semua pihak yang ikut andil dalam penelitian dan pembuatan artikel ini. Yaitu Komunitas adat Nyowok di Desa Sokong Kecamatan Tanjung Kabupaten Lombok Utara. Terima kasih juga saya ucapkan kepada pembimbing penelitian dan penulisan skripsi yaitu Bapak Harfin Zuhdi, M.A sebagai pembimbing 1 dan Bapak Heru Sunardi, S.H., M.H sebagai pembimbing 2, di Universitas Islam Negeri Mataram.

\section{DAFTAR PUSTAKA.}

Abdullah (Masyarakat), Wawancara, Dusun Kencong Desa Sokong, 12 Februari 2018

Ahmad (Tokoh Adat), Wawancara, Dusun Pengembuk Desa Sokong, 9 Maret 2018

Albi Anggito, Johan Setiawan. Metode Penelitian Kualitatif. Sukabumi: CV Jejak, 2018.

Andri (Pelaku Nyowok), Wawancara, Dusun Murjemeneng Desa Sokong, 10 Februari 2018

Anggoro, Teddy. "Kajian Hukum Masy Arakat Hukum Adat Dan Ham Dalam Llngkup Negara Kesatuan Republik Indonesia.” Jurnal Hukum Dan Pembangunan Vol. 36 (2006): 490.

Arinanto, Satya. Hak Asasi Manusia Dalam Transisi Politik Di Indonesia. Jakarta: Pusat Studi Hukum Tata Negara, 2018.

Artep (Tokoh Adat), Wawancara, Dusun Mengkudu Desa Sokong, 03 Maret 2018

Budianto, Wawancara, Pengembuk, 07 Maret 2018

Bungin, H.M. Burhan. Metode Penelitian Kuantitatif. Jakarta: Kencana, 2017.

Ifdhal Kasim, Eddie Riyadi Terre, Ed.Al. Kebenaran Versus Keadilan, Pertanggungjawaban Pelanggaran HAM Di Masa Lalu, ELSAM. Jakarta: Lembaga Studi Dan Advokasi Masyarakat, 2003.

Khalil, Rasyad Hasan. Tarikh Tasyri'. Jakarta: Amzah, 2011.

Latif (Tokoh Adat), Wawancara, Dusun Mengkudu Desa Sokong, 18 Februari 2018

Lopa, Badaruddin. Pertumbuhan Demokrasi Penegak Hukum Dan Perlindungan Hak Asasi Manusia. Jakarta: PT Yarsif Wa, 1999.

Mahmassani, Subhi. Konsep Dasar Hak-Hak Asasi Manusia. Jakarta: : PT. Tintamas Indonesia, 1979.

Mohtar, Imam. Problematika Pembinaan Pendidikan Agama Islam Pada Masyarakat. Sidoarjo: Uwais Inspirasi Indonesia, 2017.

Muhtaj, Majda El. Dimensi-Dimensi HAM Mengurai Hak Ekonomi, Sosial, Dan Budaya. Jakarta: Rajawali Pers, 2009.

Muladi, H. Hak Asasi Manusia, Hakekat, Konsep Dan Implikasinya Dalam Perspektif Hukum Dan Masyarakat. Bandung: PT Refika Aditama, 2005.

Ndaumanu, Frichy. "Kebijakan Pemerintah Daerah Terhadap Upaya Perlindungan Dan 
Penghormatan Masyarakat Hukum Adat Di

Kabupaten Alor Provinsi Nusa Tenggara

Timur.” Jurnal HAM Volume 9 (2018): 38.

Negara, menteri sekretaris. "Undang-Undang

Republik Indonesia Nomor 11 Tahun 1967

Tentang Ketentuan-Ketentuan Pokok

Pertambangan,” 1967.

—. "Undang-Undang Republik Indonesia

Nomor 5 Tahun 1960 Tentang Peraturan

Dasar Pokok-Pokok Agraria,” 1960.

Negara, Menteri Sekretaris. "Undang-Undang

Republik Indonesia1999, Undang-Undang

Republik Indonesi Nomor 39 Tahun 1999

Tentang Hak Asasi Manusia,” 1999.

—. "Undangg-Undang Republik Indonesia Nomor 1 Tahun 1974 Tentang Perkawinan,” 1974.

Nurhidayatuloh, Leni Marlina. "Perkawinan Di Bawah Umur Perspektif HAM.” Al-Mawarid XI (2011): 211.

Perb, Candra. "Penegakan Hak Asasi Manusia Di Era Globalisasi Dalam Perspektif Hukum Islam.” Al-Adalah Vol.12 (2015): 850.

Pide, A.Suriyaman Mustari. Hukum Adat. Jakarta: Prenamedia Group, 2014.

Rahmat Suryadi (Ketua Adat), Wawancara, Dusun Kencong Desa Sokong, 17 Februari 2018

Rhona K.M. Smith, Njal Hostmaelingen. Hak Asasi Manusia. Yogyakarta: Pusham UII, 2008.

Saebani, Beni Ahmad. Fiqh Munakahat. Bandung: Pusataka Setia, 2009.

Satjipto Rahardjo. Ilmu Hukum, Pencarian, Pembebasan Dan Pencerahan. Surakarta: Muhammadiyah University Press, 2004.

Situmorang, Victorio H. "Kebebasan Beragama Sebagai Bagian Dari Hak Asasi Manusia." Jurnal HAM Volume 10 (2019): 64.

Sochmawardia, Hesti Armiwulan. Diskriminasi Rasial Dalam Hukum HAM. Yogyakarta: Genta, 2013.

Soeprapto, Maria Farida Indrati. Ilmu PerundangUndangan Dasar-Dasar Dan Pembentukannya. 11th ed. Yogyakarta: Kanisius, 2006.

Soimin, Soedhar. Hukum Orang Dan Keluarga. Revisi edi. Jakarta: Sinar Grafika, 2002.

Tahir (Tokoh Agama), Wawancara, Dusun Kencong Desa Sokong, 8 April 2018

Wardatun, Atun. Jejak Jender Pada Budaya Mbojo, Samawa Dan Sasak Di Nusa Tenggara Barat. Mataram: Pusat Studi Wanita, 2009.

Yusup, Deni K. "Kodifikasi UU No. 39 Tahun 1999.” Last modified 2019.
http://dkyusupblogspot.com/2008/04/Kodifi kasi-Uu-No-39-Tahun-1999.Html. 